\section{Earliness and Yield of Tropical Winter Squash Improved by Transplants, Plastic Mulch, and Row Cover}

\author{
Matthew T. Rulevich, Francis X. Mangan, and Anne K. Carter ${ }^{1}$ \\ Department of Plant and Soil Sciences, University of Massachusetts, Amherst, \\ MA 01003-0910
}

Additional index words. Cucurbita moschata, butternut, calabaza, polyethylene mulch, spun-bonded polyester

\begin{abstract}
Field studies were conducted in 1998 and 1999 in Massachusetts to assess the effects of transplants, black polyethylene mulch, and polyester spun-bonded row cover on early fruit set and total yield of two squash (Cucurbita moschata Duchesne) cultivars: 'C42 x La Segunda' calabaza and 'Waltham' butternut. Treatment comparisons included direct-seeded or transplanted squash, with or without black polyethylene mulch, and with or without the addition of a row cover in all combinations. The use of transplants was more effective at stimulating early fruit set and highest total yield than the use of mulch and row cover. The initiation of fruit set using transplants was advanced 9 days relative to direct-seeding. Mulch and row cover treatments significantly advanced early fruit set by 7 and 5 days, respectively, but only in 1998. Yields for both winter squash were $45 \%$ higher using transplants compared to direct seeding, 19\% higher using mulch compared to bare soil, and $16 \%$ higher using row cover compared to no row cover. Total yields were higher for both cultivars in 1999 (warm, dry season) than in 1998 (cool, wet season). Use of transplants with plastic and row cover compared to the use of direct seed with neither plastic nor row cover increased yield of calabaza by $100 \%$ in both 1998 and 1999. Only the direct seeded plus plastic plus row cover treatment had yields that were similar to any of the transplanted treatments. Transplant treatments also increased number of fruit per plant and fruit size for both calabaza and butternut.
\end{abstract}

Calabaza (Cucurbita moschata Duchesne) is a tropical winter squash of great importance to many Latin American cultures. Calabaza is the most important non-root crop consumed in Puerto Rico (Maynard and Elmstrom, 1993). It is commercially grown in Puerto Rico, the Dominican Republic, Costa Rica, Mexico, and the southern portions of the United States (Pearrow and Plummer, 1991). Due to the growing populations of individuals of Puerto Rican and Dominican descent in Massachusetts and the Northeast in general (Census Bureau, 2000), there is particular interest among farmers to grow and market crops specific to this culture.

Calabaza and other winter squashes are tropical or subtropical in origin and may respond favorably to treatments that acceler-

Received for publication 25 May 2001. Accepted for publication 3 Sept. 2002. This material is based on work supported by the Cooperative State Research, Extension, Education Service, U.S. Dept. of Agriculture, Massachusetts Agricultural Experiment Station, under Project No. MAS00786. Funding was contributed through grants from the Massachusetts Dept. of Food and Agriculture, the USDA Farmers Market Nutrition Program, the UMass Public Service Endowment, and the New England Vegetable and Berry Growers'Association. Use of trade names does not imply endorsement of the products named nor criticism of similar ones not named.

${ }^{1}$ To whom reprint requests should be addressed. Email address: akcarter@pssci.umass.edu ate development and increase yields in cool conditions (Jenni et al., 1998; Waterer, 1993; Wells and Loy, 1985). Transplanting greenhouse-produced seedlings, in contrast to direct seeding, is one strategy for improving establishment with muskmelon (Cucumis melo L.), summer squash (Cucurbita pepo L.), and watermelon [Citrullus lanatus (Thunb.) Mansf.]. Transplants consistently produced higher total yields and provided for accelerated maturation compared to direct-seeded cucurbits planted on the same day (Hall, 1989; Handley et al., 1998; Hemphill and Mansour, 1986; NeSmith, 1993, 1994, 1997, 1999; Norton, 1968; Vavrina et al., 1993).

Plastic mulch is often used in conjunction with transplants. Black polyethylene mulch is used widely in U.S. production systems (Lamont, 1993) and has been the type most often studied with cucurbits (Handley et al., 1998; Hemphill and Mansour, 1986; Marr et al., 1991; Waterer, 1993; Soltani et al., 1995; Sanders et al., 1999). Spun-bonded polyester row cover, used in combination with plastic mulch, has been shown to increase total yields and advance harvest of muskmelons by approximately one week (Hemphill and Mansour, 1986; Loy and Wells, 1982; Wells and Loy, 1985). This study was designed to examine whether the use of transplants, mulch, and row cover would improve yield of calabaza in a temperate climate. Butternut squash, grown extensively in Massachusetts, was included in the study for comparison.
Cucurbitamoschata cultivars 'C42 x LaSegunda' calabaza (seed source: Univ. of Florida Gulf Coast Research and Extension Education Center, Bradenton) and 'Waltham' butternut (Johnny's Selected Seed, Albion, Maine) were evaluated at the Univ. of Massachusetts Agronomy Farm in South Deerfield, Mass., in 1998 and 1999 (42 $28^{\prime}$ lat., $72^{\circ} 35^{\prime}$ long.).

The soil was an Occum fine sandy loam variant (coarse-loamy, mixed, mesic fluventic dystrocrept). Fall-planted rye (Lolium multiflorum Lam) was turned under 1 month before planting. Urea was pre-plant broadcast at a rate providing $\mathrm{N}$ at $56 \mathrm{~kg} \cdot \mathrm{ha}^{-1}$. Black polyethylene (1.25 mil $\times 1.5 \mathrm{~m}$ wide) (Griffin Greenhouse Supply, Tewksbury, Mass.) was laid mechanically in appropriate treatments after the fertilizer was incorporated.

To produce the transplants, seeds of calabaza and butternut squash were sown in $5-\mathrm{cm}^{3}$ peat pots [Jiffy Products, Shippagan, New Brunswick, Canada] and sterile potting mix (PRO-MIX BX; Premier Horticultural, Red Hill, $\mathrm{Pa}$.). Temperature in the greenhouse was $23.8^{\circ} \mathrm{C}$ day $/ 18.3{ }^{\circ} \mathrm{C}$ night for the first 2 weeks and $23.8 / 10^{\circ} \mathrm{C}$ for the third week. Fertilizer was added at each watering with a $1 / 4$ dilution for the first week, $1 / 2$ dilution the second and third week of Peter's 20N-8.6P-16.6K (rate 2.4 g/3.6 L) (Griffin Greenhouse Supply; Tewksbury, Mass.). Light was ambient and irrigation was applied as needed.

Calabaza and butternut were transplanted or direct-seeded in the field on 5 June 1998 and 10 June 1999. The average last frost date in Deerfield, Mass., is 31 May. Plants were spaced $1.2 \mathrm{~m}$ apart in the row and 5.5 $\mathrm{m}$ between rows. Each plot consisted of 10 plants in two rows. Plots were $6.1 \mathrm{~m}$ long. A 0.9-m border was used between plots within the row. After planting, row cover (Reemay; Ken-Bar, Reading, Mass.) was laid over 0.4$\mathrm{mm}$ hoops cut to $1.7 \mathrm{~m}$ and set $1.2 \mathrm{~m}$ apart in the row for the appropriate treatments. The hoops were set to lift the cover $\approx 0.4 \mathrm{~m}$ above the plastic to prevent damage caused by winds that often prevail in the area at that time of year. Each plant or seed received $227 \mathrm{~mL}$ of $\mathrm{H}_{2} \mathrm{O}$ at planting. Remaining irrigation events are as reported later.

The treatments evaluated for calabaza and butternut compared transplants to direct-seed; mulch to bare soil; and row cover to no row cover in a factorial arrangement. Each block consisted of 16 plots $(2$ planting methods $\times 2$ mulch treatments $\times 2$ row cover treatments $\times$ 2 cultivars) in a randomized complete-block design (four replications) and utilized for analysis in both years in 1998 and 1999.

A pre-sidedress $\mathrm{N}$ test (Howell, 1999) was performed 3 weeks after planting (vine initiation). Fertilizer (Prolific, 20N-8.6P-16.6K; Terra Intl., Sioux City, Iowa) was applied as an aqueous solution at a $\mathrm{N}$ rate of $56 \mathrm{~kg} \cdot \mathrm{ha}^{-1}$ in 1998. In 1999, a pre-sidedress $N$ test indicated that further applications of $\mathrm{N}$ were not required. No pesticides of any type were used during the experiment in either year. Weeds were controlled by tillage. No irrigation was used and 


\section{Crop Production}

precipitation events are described below.

Row covers were removed at male flower opening to allow for pollination $(\approx 28$ to $35 \mathrm{~d}$ after planting). Female flowers at anthesis were counted and tagged with the date twice weekly for 10 weeks to determine the initiation of fruit set. The initiation of fruit set (IOFS) was determined by counting the days from planting to the date that $10 \%$ of the final total (determined at harvest) number of fruit set (Ibarra-Jimenez et al., 1995). Tags were removed from aborted fruits $(\leq 1 \%$ in any plot) and not counted in the final totals.

A single harvest date was chosen for each C. moschata in each year (7 Sept. 71998 and 16 Sept. 16 1999). Harvest date was based on the time that most of the plots in the field had over $50 \%$ leaf senescence. All marketable fruit within a selection were cut from the vine and cured in the field for $7 \mathrm{~d}$. Fruits were then counted and weighed. Data were processed by analysis of variance using SAS software (SAS Inst., Cary, N.C.).

\section{Results}

In 1998, weather conditions for the first 3 weeks after planting were cold, wet, and windy (Table 1). Daytime temperatures averaged $10{ }^{\circ} \mathrm{C}$, and $30.0 \mathrm{~mm}$ of rain fell over a 5 -d period. For the first $3 \mathrm{~d}$ after planting, wind gusts exceeded $50 \mathrm{kph}$ for most of the day. Uncovered plants were damaged due to wind and transpirational water loss while plants with row cover were more protected.

In 1999, environmental factors for the first 6 weeks after planting were dramatically different than in 1998. Only $80 \mathrm{~mm}$ of rain fell during this period, and June and July average temperatures were the hottest on record. However, rain occurred at critical periods of germination and stand establishment. Some wilting occurred during the day, which is typical for cucurbits, but no plants were lost due to drought conditions.

Fruit set. Environmental effects were reflected by differences in the early growth of the plants in each treatment as measured by days until the time to $10 \%$ of total fruit set (IOFS) in each year (Table 2). For both cultivars, averaged over the two years, transplant treatments reached IOFS $\approx 9 \mathrm{~d}$ sooner than direct-seeded plants. Calabaza and butternut transplants reached IOFS in $56 \mathrm{~d}$ in 1998 compared to 46 and $44 \mathrm{~d}$, respectively, in 1999. Mulch improved IOFS by $7 \mathrm{~d}$ for both cultivars in 1998, but was not significant in 1999. Use of row cover decreased the time to IOFS by $5 \mathrm{~d}$ in 1998 and was nonsignificant in 1999. When the eight individual treatments are compared (Table 3), the most striking difference observed was the comparison of the direct seeded squash without mulch and row cover with transplanted squash with mulch and row cover; averaged over both cultivars, the difference in the IOFS was 19 and $12 \mathrm{~d}$ in 1998 and 1999, respectively.

Yield. Overall, yield of calabaza was significantly higher $\left(53 \mathrm{Mg} \cdot \mathrm{ha}^{-1}\right)$ than butternut yield (29 Mg·ha ${ }^{-1}$ ) (Table 4). Yields overall were higher in 1999 compared with 1998.

Table 1. Mean rainfall and temperature at the Agronomy Research Farm in South Deerfield, Mass., in 1998 and 1999.

\begin{tabular}{|c|c|c|c|c|c|c|}
\hline \multirow[b]{2}{*}{ Month } & \multicolumn{3}{|c|}{ Rainfall (mm) } & \multicolumn{3}{|c|}{ Temp $\left({ }^{\circ} \mathrm{C}\right)$} \\
\hline & 1998 & 1999 & Normal $^{2}$ & 1998 & 1999 & Normal $^{2}$ \\
\hline May & 147 & 90 & 99 & 18 & 16 & 15 \\
\hline June & 205 & 77 & 94 & 20 & 22 & 20 \\
\hline July & 74 & 45 & 99 & 22 & 24 & 23 \\
\hline August & 31 & 115 & 103 & 23 & 21 & 21 \\
\hline September & 79 & 343 & 90 & 18 & 19 & 17 \\
\hline
\end{tabular}

${ }^{253-y e a r ~ a v e r a g e ~ f o r ~ D e e r f i e l d, ~ M a s s . ~(A m h e r s t ~ C o l l e g e ~ W e a t h e r ~ S t a t i o n, ~ M a s s .) . ~}$

Table 2. The initiation of fruit set as affected by stand establishment for calabaza and butternut fruit in 1998 and 1999.

\begin{tabular}{|c|c|c|c|c|c|c|c|}
\hline \multirow[b]{3}{*}{ Treatment } & \multicolumn{7}{|c|}{ Days to reach $10 \%$ of total fruit set } \\
\hline & \multicolumn{3}{|c|}{ Calabaza } & \multicolumn{3}{|c|}{ Butternut } & \multirow[b]{2}{*}{ Mean } \\
\hline & 1998 & 1999 & Mean & 1998 & 1999 & Mean & \\
\hline & \multicolumn{7}{|c|}{ Method of planting } \\
\hline Direct-seeded & $60^{*}$ & $50^{* *}$ & $55^{* *}$ & $59 *$ & $49^{* *}$ & $54^{* * *}$ & $55^{* *}$ \\
\hline Transplanted & 52 & 41 & 47 & 52 & 39 & 46 & 46 \\
\hline \multirow[t]{2}{*}{ Mean } & 56 & 46 & 51 & 56 & 44 & 50 & \\
\hline & \multicolumn{7}{|c|}{ Mulch } \\
\hline No mulch & $59^{* *}$ & $46^{\mathrm{NS}}$ & $52^{\mathrm{Ns}}$ & $59^{* *}$ & $44^{\mathrm{Ns}}$ & $52^{\mathrm{NS}}$ & $52^{\mathrm{Ns}}$ \\
\hline Plastic mulch & 52 & 45 & 49 & 52 & 43 & 48 & 48 \\
\hline \multirow[t]{2}{*}{ Mean } & 56 & 46 & 51 & 56 & 44 & 50 & \\
\hline & \multicolumn{7}{|c|}{ Row cover } \\
\hline No cover & $58^{* *}$ & $46^{\mathrm{NS}}$ & $52^{\mathrm{NS}}$ & $59^{*}$ & $44^{\mathrm{NS}}$ & $51^{\mathrm{NS}}$ & $51^{\mathrm{Ns}}$ \\
\hline Polyester cover & 53 & 45 & 49 & 54 & 44 & 49 & 49 \\
\hline \multirow[t]{2}{*}{ Mean } & 56 & 46 & 51 & 57 & 44 & 50 & \\
\hline & \multicolumn{7}{|c|}{ Year and cultivar } \\
\hline Year $\times$ cultivar & & & & & & & NS \\
\hline Cultivar & & & 51 & & & 50 & NS \\
\hline
\end{tabular}

${ }^{\mathrm{z}} \mathrm{IOFS}=$ days to reach $10 \%$ of total fruit set.

ns, *, ** Nonsignificant or significant by $\mathrm{F}$ test at $P=0.05$ or 0.01 , respectively.

Early fruit set contributed to higher yields for both cultivars.

Mean yields for calabaza were $64 \mathrm{Mg} \cdot \mathrm{ha}^{-1}$ with transplants and $41 \mathrm{Mg} \cdot \mathrm{ha}^{-1}$ with the direct- seeded method over both years. Butternut yields averaged $33 \mathrm{Mg} \cdot \mathrm{ha}^{-1}$ for transplanted treatments and $25 \mathrm{Mg} \cdot \mathrm{ha}^{-1}$ for direct-seeded treatments. This is an overall $45 \%$ yield increase with transplants compared to directseeded plants. Mulch treatments, compared with bare soil treatments, increased the total yield of calabaza in 1998 and 1999, and of butternut in 1999. Improvement in yield with mulch vs. bare soil represent a yield improvement of $19 \%$ for C. moschata. Use of a row cover improved the yield of butternut and calabaza, but only in 1998, the cool, wet season. Use of transplants with plastic and row cover compared to the use of direct seed with neither plastic nor row cover increased yield of calabaza by $100 \%$ in both 1998 and 1999 . Only the direct seeded C. moschata with mulch and row cover had yields that were similar to any of the transplanted treatments.

Average fruit weight. The average fruit weight of calabaza was $5.5 \mathrm{~kg} /$ fruit and of butternut was $1.6 \mathrm{~kg} /$ fruit (Table 5). Overall, only the use of transplants increased the fruit weight of either C. moschata. The use of transplants significantly increased fruit weight for calabaza in 1998 and 1999 and for butternut in 1999. Neither mulch nor row cover, nor their treatment combination (Table 3 ) affected fruit weight.

Number of fruit per plant. The average number of fruit per plant was 6.9 for butter- nut and 3.9 for calabaza (Table 6). Transplant, mulch, and row cover treatments increased the number of fruit per plant for both cultivars, with the greatest improvement seen with the use of transplants.. The use of mulch did not affect fruit number and the use of row cover only improved fruit number for calabaza in 1999. For butternut, the increase in the number of fruit per plant was improved by the use of row cover in 1998 and by the use of mulch in 1999.

\section{Discussion}

Regardless of the growing conditions or cultivars, transplants provided the most consistent improvement for fruits set, higher total yield, number of fruit per plant and fruit weight. These data are consistent with the results with muskmelon (Handley et al., 1998; NeSmith, 1994; Norton, 1968), watermelon (NeSmith, 1999), and summer squash (NeSmith, 1993). If cold weather were present at field planting, growth of either direct-seeded plants or transplants would be delayed. It would then be of great value to utilize other production practices to ensure stand establishment and subsequently improve total yields.

In 1999, using transplants, especially with plastic, lessened the time to initiation of fruit set in the field and may have lessened the severity of lower than normal rainfall on total yield. Studies of calabaza in tropical climates reported that drought conditions from the period of vegetative growth to male flowering was the most limiting factor for yield (Rios et al., 1998). 
Table 3. Effect of planting method, mulch and row cover on the individual means for the eight treatments for the initiation of fruit set, yield, average fruit weight, and average fruit number of calabaza and butternut in 1998 and 1999.

\begin{tabular}{|c|c|c|c|c|c|c|c|c|c|c|}
\hline \multicolumn{11}{|c|}{ Calabaza } \\
\hline \multicolumn{3}{|c|}{ Treatment } & \multirow{2}{*}{\multicolumn{2}{|c|}{ IOFS (day) }} & \multirow{2}{*}{\multicolumn{2}{|c|}{$\begin{array}{c}\text { Total yield } \\
\left(\mathrm{Mg} \cdot \mathrm{ha}^{-1}\right)\end{array}$}} & \multirow{2}{*}{\multicolumn{2}{|c|}{$\begin{array}{c}\text { Fruit size } \\
(\mathrm{kg})\end{array}$}} & \multirow{2}{*}{\multicolumn{2}{|c|}{$\begin{array}{c}\text { Avg no. } \\
\text { fruit/plant }\end{array}$}} \\
\hline \multirow[b]{2}{*}{ Method } & \multirow[b]{2}{*}{ Mulch } & \multirow{2}{*}{$\begin{array}{l}\text { Row } \\
\text { cover }\end{array}$} & & & & & & & & \\
\hline & & & 1998 & 1999 & 1998 & 1999 & 1998 & 1999 & 1998 & 1999 \\
\hline$\overline{\text { Seed }}$ & no & no & 67 & 52 & 28 & 43 & 4.6 & 5.0 & 2.8 & 3.5 \\
\hline Seed & yes & no & 58 & 50 & 28 & 47 & 4.0 & 5.9 & 4.0 & 3.3 \\
\hline Seed & no & yes & 58 & 51 & 33 & 41 & 4.6 & 5.8 & 3.0 & 3.0 \\
\hline Seed & yes & yes & 54 & 47 & 47 & 62 & 5.1 & 5.4 & 3.5 & 4.5 \\
\hline Transplant & no & no & 57 & 40 & 45 & 68 & 5.4 & 6.5 & 3.0 & 4.5 \\
\hline Transplant & yes & no & 48 & 42 & 51 & 77 & 5.1 & 6.7 & 4.0 & 4.5 \\
\hline Transplant & no & yes & 53 & 41 & 55 & 73 & 5.2 & 6.2 & 4.0 & 4.8 \\
\hline \multirow[t]{2}{*}{ Transplant } & yes & yes & 48 & 40 & 56 & 85 & 5.5 & 6.2 & 4.0 & 5.3 \\
\hline & & & \multicolumn{8}{|c|}{ Analysis } \\
\hline \multicolumn{3}{|l|}{ Method } & $* *$ & $* *$ & $* *$ & $* *$ & $* *$ & $* *$ & $* *$ & $* *$ \\
\hline \multicolumn{3}{|l|}{ Mulch } & $* *$ & NS & $*$ & $*$ & NS & NS & NS & NS \\
\hline \multicolumn{3}{|l|}{ Row cover } & $* *$ & NS & $* *$ & NS & NS & NS & NS & $*$ \\
\hline \multicolumn{3}{|c|}{ Method $\times$ mulch } & NS & NS & NS & NS & NS & NS & NS & NS \\
\hline \multicolumn{3}{|c|}{ Method $\times$ row cover } & NS & NS & NS & NS & NS & NS & NS & NS \\
\hline \multicolumn{3}{|c|}{ Mulch $\times$ row cover } & NS & NS & NS & NS & NS & $* *$ & NS & NS \\
\hline \multicolumn{3}{|c|}{ Row cover: no mulch } & --- & --- & --- & --- & --- & $*$ & --- & --- \\
\hline \multicolumn{3}{|c|}{ Row cover: mulch } & --- & --- & --- & --- & --- & $* *$ & --- & --- \\
\hline \multicolumn{3}{|c|}{ Method $\times$ mulch $\times$ row cover } & NS & NS & NS & NS & NS & NS & NS & NS \\
\hline
\end{tabular}

\begin{tabular}{|c|c|c|c|c|c|c|c|c|c|c|}
\hline \multicolumn{11}{|c|}{ Butternut } \\
\hline \multicolumn{3}{|c|}{ Treatment } & \multirow{2}{*}{\multicolumn{2}{|c|}{ IOFS (day) }} & \multirow{2}{*}{\multicolumn{2}{|c|}{$\begin{array}{c}\text { Total yield } \\
\left(\mathrm{Mg}^{\prime} \mathrm{ha}^{-1}\right)\end{array}$}} & \multirow{2}{*}{\multicolumn{2}{|c|}{$\begin{array}{c}\text { Fruit size } \\
(\mathrm{kg})\end{array}$}} & \multirow{2}{*}{\multicolumn{2}{|c|}{$\begin{array}{l}\text { Avg no. } \\
\text { fruit/plant }\end{array}$}} \\
\hline \multirow[b]{2}{*}{ Method } & \multirow[b]{2}{*}{ Mulch } & \multirow{2}{*}{$\begin{array}{l}\text { Row } \\
\text { cover }\end{array}$} & & & & & & & & \\
\hline & & & 1998 & 1999 & 1998 & 1999 & 1998 & 1999 & 1998 & 1999 \\
\hline$\overline{\text { Seed }}$ & no & no & 64 & 50 & 15 & 21 & 1.6 & 1.6 & 4.0 & 5.5 \\
\hline Seed & yes & no & 57 & 47 & 22 & 35 & 1.5 & 1.6 & 5.8 & 8.5 \\
\hline Seed & no & yes & 60 & 49 & 23 & 23 & 1.6 & 1.7 & 5.5 & 5.0 \\
\hline Seed & yes & yes & 55 & 49 & 23 & 34 & 1.4 & 1.6 & 6.5 & 8.0 \\
\hline Transplant & no & no & 56 & 40 & 20 & 36 & 1.6 & 1.7 & 5.3 & 8.8 \\
\hline Transplant & yes & no & 51 & 38 & 26 & 40 & 1.6 & 1.8 & 6.5 & 9.0 \\
\hline Transplant & no & yes & 54 & 38 & 28 & 37 & 1.7 & 1.7 & 6.3 & 8.3 \\
\hline \multirow[t]{2}{*}{ Transplant } & yes & yes & 45 & 38 & 31 & 46 & 1.7 & 1.8 & 7.0 & 9.8 \\
\hline & & & \multicolumn{8}{|c|}{ Analysis } \\
\hline \multicolumn{3}{|l|}{ Method } & $* *$ & $* *$ & $* *$ & $*$ & NS & $*$ & NS & NS \\
\hline \multicolumn{3}{|l|}{ Mulch } & $* *$ & NS & NS & $* *$ & NS & NS & NS & $*$ \\
\hline \multicolumn{3}{|l|}{ Row cover } & $* *$ & NS & $* *$ & NS & NS & NS & $*$ & NS \\
\hline \multicolumn{3}{|c|}{ Method $\times$ mulch } & NS & NS & NS & NS & NS & NS & NS & NS \\
\hline \multicolumn{3}{|c|}{ Mulch $\times$ row cover } & NS & NS & NS & NS & NS & NS & NS & NS \\
\hline \multicolumn{3}{|c|}{ Mulch $\times$ row cover } & NS & NS & NS & NS & NS & NS & NS & NS \\
\hline \multicolumn{3}{|c|}{ Method $\times$ mulch $\times$ row cover } & NS & NS & NS & NS & NS & NS & NS & NS \\
\hline
\end{tabular}

ss, *, ** Nonsignificant or significant by $\mathrm{F}$ test at $P=0.05$ or 0.01 , respectively.

Table 4. Yield as affected by stand establishment method, mulch, and row cover for calabaza and butternut fruit in 1998 and 1999.

\begin{tabular}{|c|c|c|c|c|c|c|c|}
\hline \multirow[b]{3}{*}{ Treatment } & \multicolumn{6}{|c|}{ Yield $\left(\mathrm{Mg} \cdot \mathrm{ha}^{-1}\right)$} & \multirow[b]{3}{*}{ Mean } \\
\hline & \multicolumn{3}{|c|}{ Calabaza } & \multicolumn{3}{|c|}{ Butternut } & \\
\hline & 1998 & 1999 & Mean & 1998 & 1999 & Mean & \\
\hline & \multicolumn{7}{|c|}{ Method of planting } \\
\hline Direct-seeded & 34 & 48 & 41 & 21 & 28 & 25 & 33 \\
\hline Transplanted & $52^{* *}$ & $76^{* *}$ & $64^{* *}$ & $26^{* *}$ & $40^{*}$ & $33^{* *}$ & $48^{* *}$ \\
\hline \multirow[t]{2}{*}{ Mean } & 42 & 62 & 53 & 24 & 34 & 29 & \\
\hline & \multicolumn{7}{|c|}{ Mulch } \\
\hline No mulch & 40 & 56 & 48 & 22 & 29 & 25 & 37 \\
\hline Plastic mulch & $46^{*}$ & $68^{*}$ & $57^{* *}$ & $26^{\mathrm{Ns}}$ & $39^{* *}$ & $32^{* *}$ & $44^{* *}$ \\
\hline \multirow[t]{2}{*}{ Mean } & 43 & 62 & 53 & 24 & 34 & 29 & \\
\hline & \multicolumn{7}{|c|}{ Row cover } \\
\hline No cover & 38 & 59 & 48 & 21 & 33 & 27 & 38 \\
\hline Polyester cover & $48^{* * *}$ & $65^{\mathrm{Ns}}$ & $57^{* *}$ & $26^{* *}$ & $35^{\mathrm{Ns}}$ & $31^{* *}$ & $44^{* *}$ \\
\hline \multirow[t]{2}{*}{ Mean } & 43 & 62 & 53 & 24 & 34 & 29 & \\
\hline & \multicolumn{7}{|c|}{ Year and cultivar } \\
\hline Year $\times$ cultivar & & & & & & & $* *$ \\
\hline Cultivar & & & 53 & 29 & & & $* *$ \\
\hline
\end{tabular}

Ns, *,** Nonsignificant or significant by $\mathrm{F}$ test at $P=0.05$ or 0.01 , respectively.
Row cover removal at first male flower, to allow for pollination, was between 9 to 14 $\mathrm{d}$ ahead for transplant plus row cover treatments compared to direct-seed plus row cover treatments. Similarly, the initiation of fruit set for calabaza in this study was advanced an average of $8 \mathrm{~d}$ for transplanted treatments in 1998 and 1999. These data are consistent with earlier work by Norton on cantaloupe (1968) and Hemphill and Mansour on muskmelon (1986) who showed that fruit maturation of transplanted crops occurred $\approx 14$ d earlier than that of direct-seeded crops.

Use of mulch showed improved total yields through both growing seasons but not to the degree exhibited by the use of transplants. Results from the two different years were possibly in response to different benefits of using mulch. In 1998, the mulch may have restricted nutrient leaching and warmed the soil to benefit plant growth. Pre-sidedress nitrogen tests (PSNT) in 1998 showed only 9 $\mathrm{mg} \mathrm{N} / \mathrm{kg}$ in bare soil plots compared with 25 $\mathrm{mg} \mathrm{N} / \mathrm{kg}$ under plastic mulch, requiring further $\mathrm{N}$ applications at vining to bare ground plots. A PSNT in 1999 indicated adequate nitrogen in mulched and bare soil plots. In 1999, moisture was probably conserved in areas surrounding the plants with mulch, diminishing the effects of a below-normal rainfall season. However, unlike 1998, the effects of mulch on cumulative fruit set and number of fruit per plant were non-significant in 1999. Diminished effects of black plastic mulch on yield during a growing season with above average temperature compared to a normal or slightly below normal growing season was found with muskmelon (Bonnano and Lamont, 1987).

The use of spun-bonded polyester row cover in 1998 buffered the effects of cold and wet weather and consequently advanced the initiation of fruit set and increased yield. Though not measured in our study, increases in heat accumulation units (Jenni et al., 1998; Wolfe et al., 1989) or increased air temperature (Bonanno and Lamont, 1987) have been offered as an explanation for row cover effectiveness in yield enhancement.

Growers looking to advance harvest or increase $C$. moschata yields will benefit from the use of transplants, plastic mulch, or row covers, but should consider cost of the materials, available resources (e.g., a greenhouse for seedling production), and available markets for the crop. No combination of production practices work best in all years. Weather factors are far too variable, and it would be difficult for a farmer to predict what inputs would work best for the whole season at planting time. The results showed that yield increases were approximately the same regardless of year or cultivar indicating that it is the plastic or row cover itself that has a beneficial affect on the environment around the plant and that the three week "headstart" from a transplant improves yields at the end of the season. Our results seem to indicate that the use of transplants provides the most consistent method of advancing early fruit set and increasing total yields. Additionally, calabaza can be considered as a viable commercial crop for Massachusetts. 
Table 5. Average fruit weight as affected by stand establishment method, mulch, and row cover for calabaza and butternut in 1998 and 1999.

\begin{tabular}{|c|c|c|c|c|c|c|c|}
\hline \multirow[b]{3}{*}{ Treatment } & \multicolumn{6}{|c|}{ Avg fruit wt (kg/fruit) } & \multirow[b]{3}{*}{ Mean } \\
\hline & \multicolumn{3}{|c|}{ Calabaza } & \multicolumn{3}{|c|}{ Butternut } & \\
\hline & 1998 & 1999 & Mean & 1998 & 1999 & Mean & \\
\hline & \multicolumn{7}{|c|}{ Method of planting } \\
\hline Direct-seeded & 4.6 & 5.5 & 5.0 & 1.5 & 1.6 & 1.6 & 3.3 \\
\hline Transplanted & $5.3^{* *}$ & $6.4^{* *}$ & $5.8^{* * *}$ & $1.6^{\mathrm{NS}}$ & $1.8^{*}$ & $1.7^{*}$ & $3.8^{* *}$ \\
\hline \multirow[t]{2}{*}{ Mean } & 5.0 & 6.0 & 5.4 & 1.6 & 1.7 & 1.7 & \\
\hline & \multicolumn{7}{|c|}{ Mulch } \\
\hline No mulch & 4.9 & 5.9 & 5.4 & 1.6 & 1.7 & 1.6 & 3.5 \\
\hline Plastic mulch & $4.9^{\mathrm{Ns}}$ & $6.0^{\mathrm{Ns}}$ & $5.5^{\mathrm{Ns}}$ & $1.5^{\mathrm{Ns}}$ & $1.7^{\mathrm{Ns}}$ & $1.6^{\mathrm{Ns}}$ & $3.5^{\mathrm{Ns}}$ \\
\hline \multirow[t]{2}{*}{ Mean } & 4.9 & 6.0 & 5.5 & 1.6 & 1.7 & 1.6 & \\
\hline & \multicolumn{7}{|c|}{ Row cover } \\
\hline No cover & 4.8 & 6.0 & 5.4 & 1.6 & 1.7 & 1.6 & 3.5 \\
\hline Polyester cover & $5.1^{\mathrm{Ns}}$ & $5.9^{\mathrm{Ns}}$ & $5.5^{\mathrm{Ns}}$ & $1.6^{\mathrm{NS}}$ & $1.7^{\mathrm{Ns}}$ & $1.6^{\mathrm{Ns}}$ & $3.6^{\mathrm{Ns}}$ \\
\hline \multirow[t]{2}{*}{ Mean } & 5.0 & 6.0 & 5.5 & 1.6 & 1.7 & 1.6 & \\
\hline & \multicolumn{7}{|c|}{ Year and cultivar } \\
\hline Year $\times$ cultivar & & & & & & & $* *$ \\
\hline Cultivar & & & 5.5 & & & 1.6 & $* *$ \\
\hline
\end{tabular}

Ns, *, ${ }^{* *}$ Nonsignificant or significant by $\mathrm{F}$ test at $P=0.05$ or 0.01 , respectively.

Table 6. Number of fruit per plant as affected by stand establishment method, mulch, and row cover for calabaza and butternut in 1998 and 1999.

\begin{tabular}{|c|c|c|c|c|c|c|c|}
\hline \multirow[b]{3}{*}{ Treatment } & \multicolumn{6}{|c|}{ Avg no. fruit/plant } & \multirow[b]{3}{*}{ Mean } \\
\hline & \multicolumn{3}{|c|}{ Calabaza } & \multicolumn{3}{|c|}{ Butternut } & \\
\hline & 1998 & 1999 & Mean & 1998 & 1999 & Mean & \\
\hline & \multicolumn{7}{|c|}{ Method of planting } \\
\hline Direct-seeded & 3.3 & 3.6 & 3.4 & 5.4 & 6.8 & 6.1 & 4.8 \\
\hline \multirow[t]{2}{*}{ Transplanted } & $3.8^{* *}$ & $4.8^{* *}$ & $4.3^{* *}$ & $6.3^{\mathrm{NS}}$ & $8.9^{* *}$ & $7.6^{* *}$ & $5.9^{* *}$ \\
\hline & \multicolumn{7}{|c|}{ Mulch } \\
\hline No mulch & 3.2 & 3.9 & 3.6 & 5.3 & 6.9 & 6.1 & 4.8 \\
\hline \multirow[t]{2}{*}{ Plastic mulch } & $3.9^{\mathrm{Ns}}$ & $4.4^{\mathrm{NS}}$ & $4.1^{\mathrm{Ns}}$ & $6.4^{\mathrm{NS}}$ & $8.8 *$ & $7.6^{* *}$ & $5.9^{* * *}$ \\
\hline & \multicolumn{7}{|c|}{ Row cover } \\
\hline No cover & 3.4 & 3.9 & 3.7 & 5.4 & $7.9^{\mathrm{Ns}}$ & 6.7 & 5.2 \\
\hline Polyester cover & $3.6^{\mathrm{NS}}$ & $4.4^{*}$ & $4.0^{*}$ & $6.3^{*}$ & 7.8 & $7.0^{*}$ & $5.5^{* *}$ \\
\hline & \multicolumn{7}{|c|}{ Year and cultivar } \\
\hline $\begin{array}{l}\text { Year } \times \text { cultivar } \\
\text { Cultivar }\end{array}$ & & & 3.9 & & & 6.9 & $\begin{array}{l}\text { NS } \\
* *\end{array}$ \\
\hline
\end{tabular}

ss, **** Nonsignificant or significant by $\mathrm{F}$ test at $P=0.05$ or 0.01 , respectively.

\section{Literature Cited}

Bonnano, A.R. and W.J. Lamont. 1987. Effect of polyethylene mulches, irrigation method and row covers on soil and air temperature and yield of muskmelon. J. Amer. Soc. Hort. Sci. 112:735-738

Elmstrom, G.W. 1973. Watermelon root development affected by direct seeding and transplanting. HortScience 8:134-136.

Hall, M.R. 1989. Cell size of seedling container influences early vine growth and yield of transplanted watermelon. HortScience 24:771-773.

Handley, D.T., S. Koller, and J.F. Dill. 1998. Growing muskmelons in Northern New England: How well do season extension practices work? UMaine Coop. Ext. Bul.
Hemphill, D.D. and N.S. Mansour. 1986. Response of muskmelon to three floating row covers. J. Amer. Soc. Hort. Sci. 111:513-517.

Howell, J. 1999. Nutrient management, p. 10-11. In: R. Hazzard (ed.). UMass Ext. Veg. and Small Fruit Program 1999 Annu. Rpt. UMass Ext., Amherst, Mass.

Ibarra-Jimenez, L., J. Flores-Velasquez, J.C. DiazPerez, and J.M. Fernanadez-Brondo. 1995. Growth and yield of muskmelon in response to plastic mulch and row cover-tunnels. Proc. 28th Natl. Agr. Plastics Congr.:122-127.

Jenni, S., K.A. Stewart, D.C. Cloutier, and G. Bourgeois. 1998. Chilling injury and yield of muskmelon grown with plastic mulches, row covers, and thermal water tubes. HortScience $33: 215-221$
Lamont, W.J. 1993. Plastic mulches for the production of vegetable crops. HortTechnology 2:35-38

Loy, J.B. and O.S. Wells. 1982. A comparison of slitted polyethylene and spun-bonded polyester for plant row covers. HortScience 17:405-407.

Marr, C., W.J. Lamont, Jr., and M. Allison. 1991. Rowcovers improve seedless watermelon yields in an intensive vegetable production system. HortTechnology 1:103-104.

Maynard, D.N. and G.W.Elmstrom. 1993. Calabaza and its production in Florida, p. 38-48. In: G. Hochmuth (ed.). Proc. 1993 IFAS Vine Crops Inst. Fla. Coop. Ext. Spec. Ser. Rpt. SSHOS-3.

NeSmith, D.S. 1993. Transplant age influences summer squash growth and yield. HortScience 28:618-620.

NeSmith, D.S. 1994. Transplant age has little influence on yield of muskmelon (Cucumis melo L.). HortScience 29:916.

NeSmith, D.S. 1997. A comparison of yields and yield components from different muskmelon (Cucumis melo L.) production systems. J. Veg. Crop Prod. 3:37-45.

NeSmith, D.S. 1999. Root distribution and yield of direct seeded and transplanted watermelon. J. Amer. Soc. Hort. Sci. 124:458-461.

Norton, J.D. 1968. Effects of field seeding and transplanting on earliness, quality, and yield of cantaloupe varieties. HortScience 3:175-177.

Orzolek, M.D. 1991. Establishment of vegetables in the field. HortTechnology 1:78-81.

Pearrow, J. and C. Plummer. 1991. Pumpkins: A commodity highlight. Vegetables and Specialties. Situation and Outlook Rpt. USDA Econ. Res. Ser. TVS 254:19-26.

Rios, H., A. Fernandez, and E. Casanova. 1998. The adaption of pumpkin varieties to non- optimal growing conditions. Cultivos-Tropicales. 19: 33-35.

Sanders, D.C., J.D. Cure, and J.R. Schultheis. 1999. Yield response of watermelon to planting density, planting pattern, and polyethylene mulch. HortScience 34:1221-1223.

Soltani, N., J.L. Anderson, and A.R. Hamson. 1995. Growth analysis of watermelon plants grown with mulches and rowcovers. J. Amer. Soc. Hort. Sci. 120:1001-1009.

Tanner, C.B. 1974. Microclimate modification: Basic concepts. HortScience 9:555-560.

Vavrina, C.S., S. Olson, and J.A. Cornell. 1993. Watermelon transplant age: Influence on fruit yield. HortScience 28:789-790.

Waterer, D.R. 1993. Influence of planting date and row covers on yield and economic value of muskmelons. Can. J. Plant Sci. 73:281-288.

Wells, O.S. and J.B. Loy. 1985. Intensive vegetable production with row covers. HortScience 20: 822-826.

Wolfe, D.W., L.D. Albright, and J. Wyland. 1989. Modeling row cover effects on microclimate and yield: I. Growth response of tomato and cucumber. J. Amer. Soc. Hort. Sci. 114:562-568. 